\title{
MEDICAL ASPECTS OF TOBACCO SMOKING AND THE ANTI-TOBACCO MOVEMENT IN BRITAIN IN THE NINETEENTH CENTURY
}

\author{
by
}

\section{R. B. WALKER*}

IN THE sixteenth and early seventeenth centuries extravagant notions had been held of tobacco as the Herba Panacea, Heilkraut, and Herbe propre à tous maux. In the course of time these had waned and tobacco had come to be consumed more often for pleasure than for health, but about 1800 tobacco was still being used as a remedy for many ills. "Tobacco is narcotic, sedative, emetic, diuretic, cathartic, and errhine, whether it be taken into the stomach or applied externally", said James Jennings in 1830. ${ }^{1}$ Tobacco smoking was recommended as an antispasmodic for asthma and a clyster or enema of infused tobacco was employed for intestinal obstruction, strangulated hernia, and strychnine poisoning, and as a diuretic for dropsy, dysury, and ischuria. ${ }^{2}$ In the cholera epidemic of 1832 tobacco was injected in the vain hope of alleviating the violent purges caused by that disease. ${ }^{3}$ However, following the isolation of the nicotine content of tobacco in 1828 and the demonstration of its poisonous qualities, doctors became wary of administering so dangerous a drug. In 1863 the British Medical Journal spoke of twenty-five years' past disuse of the tobacco enema on account of its uncertain action and sometimes fatal results. ${ }^{4}$ The revision of Pereira's Materia Medica published in 1872 in expressing the same view stated that because of the widespread use of anaesthesia surgical operation for hernia was no longer dreaded..$^{5}$ At Nottingham, said Dr. John Higginbottom in 1861, the prescription of tobacco for any ailment was rare. ${ }^{6}$ Even as an antispasmodic for asthma where tobacco could be administered in the less dangerous mode of smoking, it was going out of favour.' In 1958 H. Silvette, P. S. Larson, and H. B. Haag published a com-

*R. B. Walker, M.A., Ph.D., Associate Professor of History, Macquarie University, North Ryde, New South Wales 2113, Australia.

\footnotetext{
1 James Jennings, $A$ practical treatise on the history, medical properties, and cultivation of tobacco, London, Sherwood, Gilbert, \& Piper, 1830, p. 60.

2 A. McAllister, $A$ dissertation on the medical properties and injurious effects of the habitual use of tobacco, Boston, Pierce \& Parker, 1832, pp. 13-15. Jonathan Pereira, The elements of materia medica, London, Longman, Orme, Brown, Green, \& Longmans, 1839, pp. 872-873. Henry Wilson Cleland, The history and properties chemical and medical of tobacco, Glasgow, Bell \& Pain, 1840, pp. 59-64.

${ }^{3}$ Robert John Morris, Cholera, 1832, London, Croom Helm, 1976, p. 165.

4 Br. med. J., 1863, i: 43.

s Robert Bentley and Theophilus Redwood (editors), Dr. Pereira's elements of materia medica and therapeutics, London, Longmans, Green, 1872, pp. 620-621.

- Anti-Tobacco Journal (hereinafter cited as $A . T . J$.$) , February 1861, pp. 184-185.$

$'$ Bentley and Redwood, op. cit., note 5 above, p. 621 .
} 


\section{R. B. Walker}

prehensive account of the manifold medical uses of tobacco, past and present, but relatively few of their sources came from Britain in the nineteenth century and it seems that many of the applications of tobacco that they surveyed were in the nature of experiments rather than regular medical practice. ${ }^{8}$

In 1870 Dr. J. C. Murray prescribed snuff for bronchitis and consumption but his views were singular and unacceptable to most of his colleagues. ${ }^{9}$ Murray, who subscribed to the old-fashioned theory of four humours and four temperaments, stated that tobacco was injurious to the growing body before twenty-five years of age, unnecessary between twenty-five and thirty-five, but beneficial to those over thirtyfive. There is no sign that other doctors agreed with these remarkable findings. Apart from using tobacco as an antispasmodic for asthma, some of them recommended, or at least tolerated, smoking as a sedative. ${ }^{10}$ Medical superintendents at some lunatic asylums prescribed pipe tobacco and snuff for the patients. Thus in 1860 the annual report of the North and East Riding Lunatic Asylum disclosed that 310 pounds of tobacco and 2,016 pipes had been issued. ${ }^{11}$ In regard to the latter figure it must be remembered that clay pipes were inexpensive and easily broken.

While tobacco gradually lost the favour of the medical profession it remained a popular medicine for laymen. A high value was placed in its disinfecting power against epidemics thought to be carried by a "miasma" which tobacco smoke would destroy. ${ }^{12}$ Dr. J. C. Murray was one of the few medical men to share this belief. ${ }^{13}$ It is uncertain whether it was medical advice or lay opinion that persuaded the Guardians of the Bolton workhouse in 1882 to issue tobacco to the inmates in order to disinfect the wards during an outbreak of smallpox. ${ }^{14}$ Folk medicine also prescribed smoking in order to counteract toothache and headache. Nicotine poisoning sometimes resulted from the popular practice of packing a rotten tooth with shag or placing tobacco leaves on abraded skin and skin eruptions. ${ }^{13}$ As will be seen later, the anti-tobacco movement was not at all representative of public opinion, least of all perhaps of the lower classes, but nevertheless it was the practice to deny tobacco to sportsmen in training such as prizefighters and the Oxford and Cambridge boat race crews. ${ }^{16}$ There is no indication that this ban on smoking was inspired by medical practitioners.

Late in 1856 a leading London physician, Samuel Solly, F.R.S., gave a lecture in

${ }^{8} \mathrm{H}$. Silvette, P. S. Larson, and H. B. Haag, 'Medical uses of tobacco, past and present', Virginia med. Mthly, 1958, 85: 472-484.

John Carrick Murray, Snuff-taking, its utility in preventing bronchitis consumption, London, J. Churchill, 1870.

${ }^{10}$ [Medicus], Smoking and drinking, the argument stated for and against, London, Sampson Low, Son, \& Marston, 1871, p. 14.

"A.T.J., July 1860, pp. 100-101.

${ }^{12}$ Lancet, 1857, i: 230. The smoker's guide philosopher and friend by a veteran of smokedom, London, Hardwicke \& Bogue, 1876, pp. 91-94. W. A. Penn, The soverane herbe, London, Grant Richards, 1901, pp. 304-305. Edward Vincent Heward, St, Nicotine of the peace pipe, London, George Routledge, 1909, p. 92.

${ }^{13}$ John Carrick Murray, Smoking; when injurious, when innocuous, when beneficial, London, Simpkin, Marshall, 1871, p. 54.

${ }_{14}$ Lancet, 1882, i: 201.

1s Ibid., 1872, ii: 663; 1879, i: 296.

${ }^{16}$ Ibid., 1857, i: 468. John Laws Milton, Death in the pipe, or the great smoking question, London, G. Philip, 1857, p. 17. 


\section{Medical aspects of tobacco smoking and the anti-tobacco movement}

which he warned intellectual workers against smoking and declared that tobacco was one cause of general paralysis. ${ }^{17}$ Subsequently a tobacco controversy was pursued in the columns of the Lancet. The forty-four letters from British medical practitioners were divided almost equally between those who condemned all smoking as harmful (twenty-three) and those (twenty-one) who considered its moderate use either harmless or even beneficial as a sedative and laxative. Ailments attributed to tobacco by the critics included heart disorders, tuberculosis, paralysis, amaurosis, insanity, impotence, and spermatorrhoea. A leading if somewhat extreme tobaccophobe in the dispute was John Lizars, professor of anatomy at Edinburgh University. His Practical observations on the use and abuse of tobacco, first published in 1854, had just reached its sixth edition. Lizars charged tobacco inter alia with causing vomiting, dyspepsia, diarrhoea, apoplexy, palsy, mania, carcinoma, amaurosis, ulceration, emasculation, and congestion of the brain; solemnly he reiterated that the sole remedy was "throwing away tobacco for ever". Syphilis, he believed, might be transferred from man to man when friends indulged in the practice of taking alternate puffs from the same pipe, and he suggested that the fumes from a syphilitic smoker might infect a healthy person who had an abraded lip. ${ }^{18}$ Finally, he warned of national degeneration such as had befallen the Turks whose indulgence in tobacco had rendered them dull, indolent, and weak.

In 1860 Sir Benjamin Brodie, foundation chairman of the General Medical Council, and Sir Charles Hastings, founder and secretary of the British Medical Council, in expressing their qualified disapproval of smoking also pointed to the national degeneracy of the Turks. ${ }^{19}$ At about the same time Dr. Thomas Hodgkin maintained that in the last thirty years the British had degenerated physically because of the growing consumption of tobacco. ${ }^{20}$ Some doctors believed that the child of a smoking father (it was assumed that mothers did not smoke) could suffer from a congenital defect; in 1874 C. R. Drysdale attributed rickets to this, and in $1912 \mathrm{H}$. H. Tidswell attributed congenital debility to the same cause. ${ }^{21}$ Others believed that smoking caused impotence or reduced fertility. At a meeting of the Harveian Society, Weedon Cooke argued that as smoking reduced the sexual drive parents should not therefore find too much fault with their (unmarried) sons who smoked. ${ }^{22}$ But it is evident that neither the medical profession nor the public generally accepted their unverified theories of impotence and degeneracy. Brodie and Hastings would be given a respectful hearing but many of the other warning tobaccophobes were dismissible as cranks. Who would believe Dr. Pidduck when he alleged that at St. Giles's Hospital he had seen leeches killed instantly by the blood of smokers, or credit his observation that fleas rarely attacked smokers? ${ }^{23}$ Who could accept Dr. Copland's assertion that

\footnotetext{
${ }^{1 \dagger}$ Lancet, 1856, ii: 641 .

18 John Lizars, Practical observations on the use and abuse of tobacco, Edinburgh, George Philip, 1857, pp. 15-16.

${ }^{19}$ Letter from Benjamin Brodie, The Times, 31 August 1860, p. 9. Br. med. J., 1860, ii: 785.

${ }^{20}$ A.T.J., I June 1866, p. 86.

${ }^{21} \mathrm{Br}$. med. J., 1874, ii: 271.

22 Ibid., 1864, ii: 716.

${ }^{23}$ Lancet, 1857, i: 177.
} 


\section{R. B. Walker}

smokers seldom had grandchildren or great-grandchildren?24 Or Dr. Tidswell declaring some years later that "the only women who suffer from cancer are the wives and daughters of men who have indulged to excess in tobacco"? 25

In 1857 and later the general opinion of the profession was that moderate smoking by adults (assumed to be male) did no harm. The British and Foreign MedicoChirurgical Review, the Medical Times and Gazette, and the British Medical Journal in effect agreed with the Lancet which thought that "moderate" smoking (one or two pipes a day) was not injurious. ${ }^{26}$ As one correspondent put it:

The LANCET does not blame tobacco's Use,

(Except in youth, for that there's no excuse,)

But deprecates most strongly its abuse. ${ }^{27}$

At the time of the controversy in 1857 Dr. J. L. Milton very well exposed the exaggerations and unproven assertions of members of the anti-tobacco movement. ${ }^{28}$ Subsequently medical journals gave little attention to the question of smoking. Many books of hygiene were published by doctors for lay readers but few referred to smoking, although most had something to say about alcoholic liquor. One or two endorsed smoking as a stimulant or sedative. ${ }^{29}$ It was alleged that most doctors smoked ${ }^{30}$ As a whole doctors tolerated or approved of "moderate" smoking.

In 1860 Sir Benjamin Brodie had endorsed occasional smoking as a solace to the tired man but had condemned regular smoking as harmful. ${ }^{31}$ In 1864-65 the popular physician Dr. B. W. Richardson maintained that smoking produced functional disorders, which ceased when tobacco was discontinued, but that it did not cause organic disease..$^{32}$ As a sedative a daily pipe benefitted hard manual workers; until society could "equalise labour" and "remove the call for an artificial necessity of an artificial life" tobacco must be accepted as "one of the least hurtful of luxuries", no worse then tea or sugar. ${ }^{33}$ But in 1871 Richardson himself gave up pipe smoking and in his Diseases of modern life (1876) presented a somewhat incoherent account. Repeating his old view that smoking caused no organic mischief, Richardson added a warning against smoking as it induced organic modifications of function and smoking parents would breed physically inferior offspring. ${ }^{34}$ Richardson's advice seemed at variance with his own earlier researches. However, the lead in the anti-tobacco movement was not taken by Richardson but by more extreme opponents such as Professor John Kirk of Edinburgh University and Dr. C. R. Drysdale, president of the

${ }^{24}$ A.T.J., April 1861, pp. 214-215.

${ }^{25}$ Herbert Henry Tidswell, The tobacco habit, its history and pathology, London, J. \& A. Churchill, 1912 , p. 76.

${ }^{26}$ Br. for. med.-chir. Rev., 1861, 1: 104-121. Med. Times Gaz., 1857, 1: 289-290; 1860, 2: 243. Br. med. J., 1857, i: 135, 174; 1870, i: 267, ii: 294. Lancet, 1857, i: 354-355; 1872, i: 770; 1879, i: 131; 1882, ii: 765.

${ }^{27}$ Lancet, 1857, i: 418.

28 Milton, op. cit., note 16 above, passim.

29 Horace Benge Dobell, $A$ manual of diet, London, H. K. Lewis, 1882, p. 39. George Black, Family health book, London, Ward, Lock, 1892, p. 39.

${ }^{30}$ Letter by "T. F.", English Mechanic, 28 November 1873, p. 264.

31 Lancet, 1860, ii: 243.

${ }^{32} \mathrm{Br}$. med. J., 1864, ii: 425; Benjamin Ward Richardson, For and against tobacco, London, John Churchill, 1865, p. 21.

33 Ibid., p. 106.

34 Benjamin Ward Richardson, The diseases of modern life, London, Macmillan, 1876, pp. 27, 43, 74. 


\section{Medical aspects of tobacco smoking and the anti-tobacco movement}

Malthusian League. Inter alia Drysdale attributed bronchitis, spongy gums, bad teeth, vertigo, insanity, dyspepsia, diarrhoea, debility, piles, pallor, palpitations, and paralysis to tobacco. ${ }^{35}$

Doctors spoke on the basis of their clinical impressions; statistics, if collected at all, were on a narrow and unrepresentative basis. The wisest conclusion, said Professor E. A. Parkes, was to avoid a conclusion. ${ }^{36}$ Nevertheless, the indiscriminate shooting by the anti-tobacco medicos did strike some real targets. Lung cancer, still rare in the nineteenth century, was scarcely one of them. ${ }^{37}$ There is sufficient evidence that in the nineteenth century the smoke of pipe and cigars (unlike the later dangerous cigarette) was rarely inhaled into the lungs. ${ }^{38}$ Fearing the effect of the "empyreumatic oils" or tars as well as the nicotine content, some doctors advised cigar smokers to smoke only half so as to leave the oils in the butt. ${ }^{39} \mathrm{Dr}$. De Wolfe treated a very heavy pipe smoker by limiting him to two clean pipes a day..$^{40}$ At this time workingmen commonly smoked clay pipes which could be cleaned by being roasted near the fire, a purification which was often neglected. Victorian doctors correctly linked lip cancer to pipe smoking. Sir Astley Cooper, in 1827 President of the Royal College of Physicians, is said to have made this link as did Professor Lizars and Dr. Hodgkin in the fifties and Dr. B. W. Richardson in $1865 .^{41}$ Opinions differed as to whether the trouble arose merely from irritation from the hot stem of the pipe or also from the smoke, in which case cancers of the pharynx and larynx were also attributed to tobacco. In $1903 \mathrm{Sir}$ Thornley Stoker said he had operated on 350 cases of lip cancer in Ireland; only three were women and these women all smoked the dudheen. The disease was less common at Dublin where briar pipes were smoked, and it rarely affected non-smokers. ${ }^{42}$

Smoking is now known to be positively correlated with coronary artery disease, bronchitis, and emphysema..$^{43}$ Nineteenth-century doctors spoke of "tobacco heart" and "tobacco angina" to refer to a number of disorders ranging from the most serious troubles to the minor palpitations that usually cleared up when heavy smokers moderated their smoking habits. ${ }^{44}$ Nineteenth-century physicians also correctly

${ }^{35} \mathrm{Br}$. med. J., 1864, ii: 716; 1874, ii: 318; letters from C. R. Drysdale, English Mechanic, 28 February 1873, p. 581, 10 October 1873, p. 91; Charles R. Drysdale, Tobacco and the diseases it produces, London, Baillière, Tindall \& Cox, 1875, passim.

${ }^{36}$ E. A. Parkes, letter to W. Pratt, Lancet, 1880, i: $28-29$.

${ }^{37}$ In the 1920s Dr. Edward Mellanby of the Medical Research Council observed an apparent connexion at Nottingham between lung cancer mortality and the free issue of cigarettes; see Sir David Cuthbertson, 'Historical notes on the origin of the association between lung cancer and smoking', J. R. Coll. Physcns, 1967, 2: 191-196.

38 Br. med. J., 1857, i: 175; 1896, i: 165. Lancet, 1882, ii: 765 . Milton, op. cit., note 16 above, p. 36. English Mechanic, 22 May 1874, p. 255, 5 June 1874, p. 306. 'Tobacco: its use and abuse', Cornhill Magazine, 1862, 6:610.

${ }^{39}$ Ibid.

${ }^{40}$ Lancet, 1876, ii: 811.

4 Jennings, op. cit., note 1 above, p. 64. A.T.J., November 1858, p. 13; November 1859, p. 132. Richardson, op. cit., note 32 above, pp. 61-63.

${ }^{42}$ Sir Thornley Stoker, 'On cancer of the lips', Practitioner, 1903, 70: 577-584.

${ }^{43}$ United States Department of Health, Education and Welfare, Smoking and health, report of the advisory committee of the surgeon-general of the public health service, Washington, D.C., 1964, p. 29.

${ }^{44}$ Tobacco and disease, the substance of three letters reprinted with additional matter from the English Mechanic, London, N. Truebner, 1872, p. 13. Richardson, op. cit., note 34 above, p. 300 . Cornelis van Proosdij, Smoking, its influence on the individual and its role in social medicine, Amsterdam, Elsevier, 1960, pp. 128-129. 


\section{R. B. Walker}

identified another disorder caused by smoking: "tobacco amblyopia" or dim vision without detectable organic lesion. ${ }^{45}$ Modern research shows that less than one per cent of eye patients now suffer from this complaint. It is linked to pipe rather than cigarette smoking and, judging from the amount of attention given to it in the seventies and eighties, may have been much commoner at that time. Aggravating factors are ill health, consumption of alcohol, and poor nutrition and deficiency in vitamin B12.46

The largely lay anti-tobacco movement made extensive use of the doctors' condemnations of the drug. Disregarding medical opinions favourable to tobacco, the zealots indiscriminately diffused the most extravagant assertions of obscure medicotobaccophobes. The doctors had spoken of harmful physiological and psychological effects; from this point the lay anti-tobacconists enlarged upon the mental, moral, social, and economic harms of tobacco smoking. Before discussing the movement in detail, we may briefly consider the nature of the arguments. They consisted largely of personal impressions and of assertions unsubstantiated by research or sound evidence. Whenever anything untoward happened to a smoker it became the substance of a lay sermon argued on post hoc ergo propter hoc lines. Adequate statistics were lacking. One of the few surveys undertaken (it was repeatedly quoted) was that of M. Bertillon in 1855. Bertillon had found the fifty-eight non-smoking students at the Ecole Polytechnique to be academically much superior to their 102 smoking comrades. ${ }^{47}$ But many of the arguments used by the anti-tobacco movement might be traced back to royal lineage in James I's Counter-blaste to tobacco published in 1604. The tobaccophobes tended to regard smoking as an indication of moral laxity, associating it with crime and irreligion. ${ }^{88}$ It was the Russian writer Count Leo Tolstoy who most elaborately explained how alcohol and tobacco dulled moral and also artistic sensibilities and suppressed the warning voice of conscience. Almost all gamblers, lunatics, and courtesans smoked tobacco, he said, and "among the female sex the women who lead blameless regular lives are the least frequently addicted to smoking". ${ }^{49}$ In English fiction the most extreme picture of the physical, intellectual, and moral degeneration wrought by cigarette addiction was presented in Ranger Gull's novel The cigarette smoker, being the terrible case of Uther Kennedy..$^{50}$

According to the opponents of tobacco, the weed wrought great harm both to the individual and to society. Some men, they said, lounged away Sunday morning puffing their pipes and were ashamed to come to church in clothes reeking with stale tobacco. ${ }^{31}$ Smoking provoked drinking and thereby drunkenness. Tobacco and alcohol

45 'The tobacco question', Dublin Univ. Mag., 1871, 8: 287.

${ }^{46}$ H. Silvette, H. B. Haag, and P. S. Larson, 'Tobacco amblyopia', Amer. J. Opthalm., third series, 1960, 50: $71-100$.

${ }^{47}$ English Mechanic, 7 February 1873, pp. 508-509.

${ }^{48}$ A.T.J., December 1858, p. 20. William Ritchie, The workman's pipe: what it is and what it does, London, S. W. Partridge, 1871, p. 32.

${ }^{49}$ Leo Tolstoy, 'The ethics of wine-drinking and tobacco-smoking', Contemporary Review. 1891, 59: 179.

so Cyril Arthur Edward Ranger Gull, The cigarette smoker, being the terrible case of Uther Kennedy, London, Greening, 1902.

${ }^{s 1} A . T . J ., 1$ June 1867 , p. 63. 
production and consumption were alike repugnant as a diversion of land, capital, labour, time, and effort from other and better purposes. ${ }^{32}$ Expenditure on tobacco was seen as a major cause of secondary poverty. Other anti-social consequences were annoyance to others by the pollution of air in trains, halls, and public places, fires, and explosions in mines caused by the careless or prohibited use of matches. Smokers fouled the air with their fumes and the floor with their expectorations, thus causing offence to others. A commercial traveller thus expressed his disgust at the spittoons in temperance hotels, all of which banned alcohol and none tobacco..$^{33}$

Persons who regarded pleasure with suspicion, persons who imposed discipline on themselves in order to fulfil one great commitment, tended to oppose tobacco. In some cases, such as that of Wilson Carlile, founder of the Church Army, religious conversion and the rejection of tobacco were closely linked. ${ }^{54}$ It is said that the Evangelical Sir James Stephen gave up snuff as he could find no justification in faith for taking it, and that "he once smoked a cigar and found it so delicious that he never smoked again".ss The less dedicated Ernest Pontifex at the time of his conversion locked up his pipes but soon resumed smoking even while his religious commitment remained..$^{36}$ In 1887 in response to a questionnaire from the English Anti-Tobacco Association, twenty-three of the thirty-four English bishops replied that they did not smoke. The remaining eleven apparently contained some smokers and it may be noted that only one of the twenty-three expressly commended the work of the Association. ${ }^{37}$ The Salvation Army did not allow its bandsmen and officers to smoke and the Plymouth Brethren would not take tobacco, but the "denomination-type" churches (Nonconformists) and the "church-type" (Anglicans and Catholics) left the matter to individual decision. Smoking ministers such as the Rev. Charles Spurgeon, who boldly declared that he would smoke a cigar for refreshment and to the glory of God, were a standing disproof of the alleged connexion between smoking and irreligion. In fact with the gradual substitution of fruit juice for fermented wine in the sacrament of holy communion, the teetotallers had greater influence on the Nonconformist denominations than had the tobaccophobes. The rules of the Wesleyan Methodist Connexion asked the ordinand, "Do you take no snuff, tobacco, or drams?", but many Wesleyan ministers did not take this obligation to bind them in the matter of smoking. Among the Wesleyans the opponents of tobacco made no progress. It seems that Anglican clergy and Protestant ministers smoked privately and discreetly. The "Dossers' Parson" and Edmonton missioner Mr. Collings was a rare exception to this caution. Determined to induce workingmen to worship, he stood at the door smoking a cigar and handing out threepenny shag with an invitation to puff away during the service. $^{\text {s8 }}$

The literature produced by the mid-century anti-tobacco movement was moralistic.

s2 Ibid., November 1858, pp. 2, 6-7.

s3 Ibid., February 1859, p. 45.

s4 Beacon Light, July 1906, p. 83.

ss Noel Annan, Leslie Stephen, his thought and character in relation to his time, London, MacGibbon \& Kee, 1951 , p. 14.

s6 Samuel Butler, The way of all flesh, London, Bell \& Pain, 1903, pp. 230-233.

57 Tobacco Trade Review (hereinafter cited as T.T.R.), 1 November 1887, p. 276.

s8 Morning Leader, 15 October 1887, p. 8. 


\section{R. B. Walker}

It urged smokers to rid themselves of their bad habit by moral effort. By the end of the century heavy smoking was beginning to be seen as a disease, an addiction based on a physiological dependence. This was the viewpoint of Ranger Gull's novel in 1902, but the older attitude co-existed. If smoking were to be considered a vice it chiefly concerned pastors and evangelicals; if a disease it was a matter for physicians. A parallel may be drawn with attitudes to the taking of opiates. ${ }^{39}$ However, in actuality the dichotomy was not so sharp. Pastors smoked, doctors smoked, and the latter, although desirous of establishing themselves as a profession with particular responsibilities in society, did not as yet set themselves up as the expert deliverers of smokers from their thrall.

There were two main societies formed to oppose smoking in England. The AntiTobacco Society was established at London in 1853 with impressive support from leading churchmen such as the bishop of Ripon, the dean of Carlisle, and canon Hugh Stowell of Manchester, and leading members of the medical professions, including Sir John Forbes, physician to the queen, and Samuel Solly, F.R.S. Thirty-four of its "promoters" were doctors. It had its well-to-do philanthropists in the persons of Sir Walter Trevelyan, Joseph Pease, and Samuel Morley, but it never fulfilled the promise of its birth. Few branches were formed and, so far as we can judge from the tract-like pages of the Anti-Tobacco Journal, the activity of the society was concentrated solely in the person of its secretary, Thomas Reynolds. He was appointed at 200 guineas a year but in fact never received more than $£ 75$; the income of the society (only $£ 209$ for the two years 1854-56) was quite incommensurate with the wealth of its founders and members. Reynolds, who seems to have had some private means, gave up his job to work full-time for the society in lecturing, writing, and distributing tracts, and editing the Anti-Tobacco Journal. After his death in 1875 the Journal was carried on by his daughter until her death in 1900 . By that time the society was more nominal than real. The proceedings of the society are now lost, but judging from the Journal we may suspect that defects in the secretary's personality and leadership were one cause of the society's ineffectiveness. An ex-smoker, he extravagantly attributed all manner of ills, physical, mental, moral, and social, to smoking, and there is little indication in the Journal that he appreciated the psychology of smoking. At a Cambridge meeting inter alia he declared that nine-tenths of all the undergraduates who failed were "plucked" because of their addiction to tobacco; at this "some crowed like cocks, some yelled like hounds, some groaned, some grinned, most of them mounted the forms with their back towards the lecturer ...". Reynolds was taken into protective custody and so ended the Cambridge Tobacco Riot. ${ }^{60}$

In November 1867 the Manchester and Salford Anti-Tobacco Society was formed with support from local clergy, doctors, and others. It soon altered its name to the North of England Anti-Tobacco Society and in 1872 to the English Anti-Tobacco Society, changes which attest the widening of its support. In 1877 there were 600 financial members, income was $£ 456$, and over 84,000 publications were issued

\footnotetext{
39 Virginia Berridge, 'Victorian opium eating: responses to opiate use in nineteenth century England', Victorian Studies, 1978, 21: 456-457.

${ }^{60}$ Thomas Reynolds, $A$ memento of the Cambridge tobacco riot, London, Houlston \& Stoneman, 1854 , p. 5.
} 
gratuitously and 62,000 sold. ${ }^{61}$ From May 1876 it had been able to publish a Monthly Letter. Believing that pipe and pot were allied foes, it strove to convert the temperance movement and persuade it to adopt the "double pledge" of abstinence from liquor and from tobacco alike. Earlier, the Anti-Tobacco Society at London had had strong links with the temperance movement, for among its members were Sir Walter Trevelyan, first president of the United Kingdom Alliance, Joseph Thorp, president of the British Temperance League, and Thomas Smithies, editor of the Band of Hope Review and of the British Workman. ${ }^{62}$ Between 1897 and 1904 and again between 1907 and 1909 Beacon Light, the monthly organ of the Manchester society, published twenty-eight biographies and obituaries of some of its chief officers and supporters. Of these three of the individuals were temperance lecturers, ten had held office in the United Kingdom Alliance, and fifteen were associated with other temperance bodies, leaving only one out of the twenty-eight whose temperance allegiance was not stated. ${ }^{63}$ In nineteen cases in which religion was indicated one was Anglican and eighteen were Nonconformists. It is known that Joseph Livesay, father of teetotalism, supported the English Anti-Tobacco Society although he devoted most of his energies to other objects. ${ }^{64}$ Peter Spence, self-made man, inventor, and manufacturer, and leading teetotaller was one of the founders of the society and his son Frank its honorary secretary for many years. The versatile theist and radical Professor Frank Newman who described himself as "anti-slavery, anti-alcohol, anti-tobacco, anti-everything" and in a broad sweep opposed vaccination, vivisection, and meat-eating, was another leading member of the society. ${ }^{65}$

In the literature of the anti-tobacco movement there is no suggestion that any of its members were drinkers; in the ranks of the teetotallers some were certainly smokers. ${ }^{66}$ This must be the reason why temperance groups were reluctant to raise so divisive an issue. However, as juvenile smoking was almost universally condemned, the double pledge was applied to some of the juvenile sections of temperance bodies. This was true of the Good Templars. ${ }^{67}$ In 1847 the first Band of Hope had been formed at Leeds to bring up children as teetotallers and as the movement spread, pushed along by the zeal of its respectable working-class leaders, some Bands imposed the double pledge, others the single pledge from liquor alone. ${ }^{68}$ The Lancashire and Cheshire Union, one

${ }^{61}$ Tenth annual report of the English Anti-Tobacco Society, 1877, Manchester, English Anti-Tobacco Society, 1878.

62 Peter Turner Winskill, The temperance movement and its workers, London, Blackie, 1892; and idem. Temperance standard bearers of the nineteenth century, Liverpool, [the author], 1897, have useful biographies. See also, Brian Harrison, Drink and the Victorians. The temperance question in England 1815-1872, London, Faber, 1971.

${ }^{63}$ The exception was W. P. Burnley (Beacon Light, December 1907, pp. 133-134). Principles of selection for biographies in Beacon Light were not stated.

64 North of England Anti-Tobacco Society, report of the annual meeting, 1871, Manchester, North of England Anti-Tobacco Society, 1871, p. 5.

${ }^{6 s}$ William Robbins, The Newman brothers, London, Heinemann, 1966, pp. 149-150. See also, Richard French, Antivivisection and medical science in Victorian England, Princeton University Press, 1975.

${ }_{66}$ T.T.R. 11 September 1869 , p. 133. According to the Monthly Letter of the English Anti-Tobacco Society, December 1876, 43 per cent of the Good Templars in Lincolnshire were smokers but of those who broke their pledge 68 per cent were smokers.

${ }^{67}$ Beacon Light, June 1897, p. 85, April 1899, p. 42.

68 Ibid., June 1897, p. 85. Lillian Lewis Shiman, 'The Band of Hope movement: respectable recreation for working-class children', Victorian Studies, 1973, 18: 49-74. 


\section{R. B. Walker}

of the largest, recommended the double pledge. In regard to other temperance groups, the Rechabites prohibited smoking at their meetings but did not impose the double pledge; in 1899 it was decided to offer a voluntary pledge against tobacco to the juveniles. ${ }^{69}$ Apart from the juvenile sections, the anti-tobacco movement had little success. As early as 1842 Thomas Cook had been in conflict with other teetotallers over whether smoking should be allowed in temperance coffee houses. He opposed it and in 1841-42 published the Anti-Smoker and Progressive Temperance Reformer, which is said to have been the first anti-smoking organ in the world. ${ }^{70}$ But the smokers won. Preferring to wean workingmen from the pot rather than the pipe, the temperance reformers sold tobacco and provided smoking rooms in their coffee houses and temperance hotels. ${ }^{71}$ One guide advised that smoking should not be confined to one room but be allowed everywhere so that the visitor might feel thoroughly at home. ${ }^{22}$

In 1908 the Children Act made it an offence to sell cigarettes to a juvenile under sixteen years of age and enabled police to seize the cigarettes of any boy or girl seen smoking in a public place. ${ }^{73}$ This was exactly fifty years after the Anti-Tobacco Society had petitioned Parliament to ban juvenile smoking in the streets and it may be regarded as partly attributable to the anti-smoking movement. Boys of course had for longer secretly experimented with their fathers' pipes and sucked mace or orris root to conceal the deed from their parents. ${ }^{74}$ In 1871 Mrs. Harriette Noel-Thatcher had asked, "who has not seen groups of juveniles, ranging from eight to fourteen years of age, ransacking their pockets for half-pence, and despatching one of their number to the cigar shop?". ${ }^{75}$ "Old Fogey" recollected how in the forties he had as a boy smoked the stem of a woodbine and one of his fellows, having been chastized, had stolen the master's cane, cut it up, and smoked the small pieces at a celebratory picnic. ${ }^{76}$ Boys smoked because they thought it manly, but the strong pipe tobacco of the day induced nausea and "tobacco heart" in those who had not acquired a tolerance for the drug. Cigarettes were cheap, mild, and easy to buy in penny lots at sweetshops, and the native woodbine soon yielded to the Woodbine. Public concern at increased juvenile smoking was aroused. A survey undertaken in 1965 showed that of men then aged sixty or older thirty-one per cent said that they had started smoking before they had reached the age of sixteen. ${ }^{77}$ Statistics also show that those men who have not started smoking by the age of twenty-four usually remain non-smokers afterwards.

${ }^{69}$ Beacon Light, August 1899, p. 91.

${ }^{70}$ Thomas Cook, Anti-smoker selections, first series, science v. tobacco, a selection of original medical testimonies, London, Elliot Stock, [1875], pp. 1-5. John Pudney, The Thomas Cook story, London, Michael Joseph, 1953, pp. 33-38, 65.

${ }^{7}$ Edward Hepple Hall, Coffee taverns, cocoa houses, and coffee houses, London, S.W. Partridge, [1878], p. 110.

${ }^{2}$ Practical hints for the management of coffee taverns, London, Coffee Tavern Co. Ltd., 1878, p. 6.

738 Edward VII, c. 67, ss. 39-42, 21 December 1908.

74 “W.C.", 'Boy-smokers', Chambers' Journal, 1878, 172: 641.

${ }^{75}$ Mrs. Harrriette Noel-Thatcher, The fascinator, London, W. Tweedie, 1871, p. 13.

16 T.T.R., 1 September 1887, pp. 220-221.

$"$ P. N. Lee, Statistics of smoking in the United Kingdom, London, Tobacco Research Council, 1976, table $33 \mathrm{M}$. 


\section{Medical aspects of tobacco smoking and the anti-tobacco movement}

It is a curious fact that while the medical profession in the nineteenth century was almost unanimous in believing that tobacco was harmful to children, there was no scientific research about the effects of smoking on the growth and health of children. ${ }^{78}$ Publicity in 1900 was given to the opinion of the chief inspector of recruiting at Manchester that one-third of the rejected volunteers (only 4,030 out of 12,235 examined were accepted) suffered from "smoker's heart"..$^{79}$ In 1904 an interdepartmental committee on physical deterioration recommended legislation to prohibit the sale of tobacco to children and to ban its sale in sweetshops. ${ }^{80}$ Fears of national degeneration and of defeat in the struggle for survival by the fittest now gave added strength to the old anti-smoking movement. New groups directed not against all smoking but solely against juvenile smoking emerged, the most important of them being the International Anti-Cigarette League, founded in London in March 1901 and numbering Winston Churchill and Baden-Powell among its promoters. In 1904 eleven lords, five bishops, four Members of Parliament, and numerous headmasters, church leaders, and medical men subscribed to a manifesto against juvenile smoking. ${ }^{81}$ Here was a movement on a different basis from the agitation of provincial, mainly Nonconformist, anti-tobacconists. Richard Rigg, a young Liberal barrister, non-drinker and treasurer of the Anti-Smoking Association at Manchester, was the first to present a bill against juvenile smoking. ${ }^{82}$ These and other private bills made little progress, but a House of Lords select committee in 1906 endorsed the principles of prohibiting the sale of tobacco to children and banning juvenile smoking in public places. ${ }^{83}$ Unlike local option and the question of licence reduction with or without compensation, action against juvenile smoking did not become a party question. The relevant clauses in the Children Bill of 1908 passed without much difficulty. Precedents for the legislation could be found in several foreign countries, in most of the states of the United States, and in New Zealand and Australia.

Apart from this act the anti-tobacco movement had little success; it does not seem that it dissuaded many people from smoking. The tobacco trade was not seriously threatened and it either ignored or ridiculed the movement. As a whole smokers dismissed the possible danger to their health although the manufacturers of the Biltor pipe, after quoting Dr. B. W. Richardson's condemnation of smoking, explained that their special filters safeguarded the smoker's health:

No more the smut your teeth will stain,

No more old 'Nic' will fire your brain,

For filtered pure, no smoke can fly

To choke the breath or film the eye. ${ }^{84}$

However, Biltor's appeal to health was exceptional and the anti-tobacco movement had little public impact. This was the more remarkable in view of the fact that one-

\footnotetext{
78 Evidence of Professor D. T. Cunningham and Dr. R. Hutchison to the interdepartmental committee on physical deterioration, Parliamentary Papers, 1904, XXXII, QQ. 2369-2372, 10109.

79 Beacon Light, June 1902, p. 66; Parliamentary Papers, 1904, XXXII, 278.

80 Parliamentary Papers, 1904, XXXII, 82 and 98.

1 The Times, 19 January 1904, p. 10.

82 Beacon Light, March 1903, p. 28.

${ }^{83}$ House of Lords Sessional Papers, 1906, II, 149-150.

${ }^{84}$ Leaflet for Biltor pipe in 'Tobacco III', John Johnson collection, Bodleian Library, Oxford.
} 
quarter or one-third of all men were non-smokers and at the end of the century, even after the popularization of the cigarette, few women smoked. ${ }^{85}$ To judge from the respondents to Reade's questionnaire in 1882, some non-smokers had no general objection to smoking, although they themselves had no wish to smoke, while others had a strong dislike of the practice as physically harmful, dirty, and obnoxious to others. ${ }^{86}$ Among those who actively disliked smoking were Lord Melbourne, Prince Albert, the Duke of Wellington, W. E. Gladstone, John Ruskin, the Rev. James Martineau, and Professor J. E. B. Mayor. The anti-smoking movement failed to exploit the potential of such as these, and to harness the power of the non-smoking fair sex. A list of subscribers to the English Anti-Tobacco Society in 1877 contained 323 names, but only eleven of them were female. Perhaps some people were repelled by the excesses of the anti-tobacco movement. The Rev. J. Q. A. Henry in 1906 for instance asserted that cigarettes were manufactured in filthy conditions by workers suffering from leprosy, that opium was mixed in to make the product addictive, that the cigarette papers contained arsenic, and that "the cigarette is the devil's device to kill young America, and young Britain as well"'.87 Those able to give rational study to the question might have concluded in 1900 that the medical evidence, except in regard to certain ailments (discussed above in this article) was not conclusive. Yet laity and medical profession alike firmly believed that smoking harmed children, although measurements and statistics to prove this were then lacking.

SUMMARY

At the start of the nineteenth century doctors prescribed tobacco for a number of ailments including asthma, hernia, and intestinal obstruction, but after the nicotine content of the plant was isolated in 1828 and its poisonous character recognized tobacco came to be less used. Folk medicine, however, continued to value tobacco and to trust in the disinfecting power of tobacco smoke. In 1817 correspondence in the Lancet was almost equally divided between those who considered tobacco smoking as always harmful and those who sanctioned "moderate" smoking as harmless or even beneficial. Professor Lizars of Edinburgh University and some other medical men attributed a wide range of serious diseases to smoking but the medical journals and the profession as a whole regarded "moderate" smoking as harmless for (male) adults. All agreed that juveniles should not smoke and most believed, at least until cigarette smoking increased in the eighties, that women did not smoke.

The anti-tobacco movement used medical and non-medical arguments against smoking. The two main societies, based on London and Manchester respectively, were supported by doctors, clergy, and others. The Manchester association seems to have had strong links with Nonconformity and teetotal associations, but neither the churches nor the temperance movement as a whole condemned the moderate use of tobacco. The first significant legislative restriction on smoking was the Children Act of 1908 which banned the sale of cigarettes to juveniles under sixteen years of age. However, in 1900 only a minority of doctors believed that moderate smoking (especially pipe smoking) was harmful to adults.

${ }^{8 s}$ These points are to be dealt with in a separate article by the writer.

${ }^{86}$ A. A. Reade, Study and stimulants, Manchester, A. Heywood, 1883, pp. 34-35, 52-54, 80-85, 94-95, 110.

${ }^{87}$ John Quincy Adams Henry, The deadly cigarette; or, the perils of juvenile smoking, London, Richard J. James. 1906, pp. 30-38. 